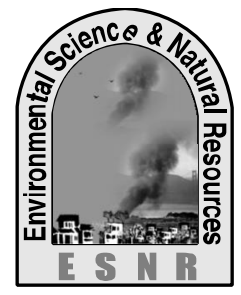

\title{
Assessment of Spatio-Temporal Changes of Land Use in Tangail Municipality Using GIS
}

\author{
S. A. Mamun ", H. A. Runa, M. M. M. Hoque, S. Sheikh and R. H. Arif \\ Department of Environmental Science and Resource Management, \\ Mawlana Bhashani Science and Technology University, Tangail-1902, Bangladesh \\ "Corresponding author: shamim084du@ gmail.com
}

\begin{abstract}
Tangail district has undergone dramatic changes in its physical form through urbanization. Here, agricultural land and vegetation cover have been transformed into built-up areas; fallow land and water bodies into reclaimed built-up areas. The aim of this research was to develop land use and land cover (LULC) maps of the Tangail Municipality area in 2001, 2011 and 2017. Landsat (TM) Satellite images of the year 2001, 2011, and 2017 were used. On-screen digitization method was applied to prepare the final maps with four classes (water bodies, vegetation, agricultural land, and settlement area) of land use. The study reveals that the settlement area was increasing over the study period, and mainly agricultural land and water body were converted into settlement. It was found that about $48.73 \%$ areas were covered with the settlement area in 2017. Similarly, a substantial increase was seen in the areas of vegetation as about 824.49 ha land added to this category throughout the study years. In contrast, the agricultural land ( $786.30 \mathrm{ha})$ and water body (114.73 ha) were declined between 2001 and 2017.
\end{abstract}

Key words: GIS, Land use, Natural resources, Remote sensing

\section{Introduction}

Land is one of the prime natural resources of a country and also land use change, including land conversion from one type to another and land cover modification through land use management has greatly altered a large proportion of the earthôs land surface to satisfy mankindôs immediate demands for natural resources (Foley et al., 2005). Land use and land cover change has been recognized as an important driver of environmental change on all spatial and temporal scales (Turner et al., 1994). Land use is characterized by the activities of the people that involve using of lands for habitation, agricultural, forestry and industrial development and all sorts of small and large scale livelihood activities using lands of different cover types (FAO/UNEP, 1999). Humans have been altering the earthôs surface to produce food through agricultural activities for centuries (Reid et al., 2000) and increasingly contributing towards modification of global environment (Ojima et al., 1994). Human population growth represents the primary driving force in land use change (Vitousek et al., 1997). Asia is the home to nearly 3.5 billion people among a worldwide population of more than 6 billion, and the worldôs two most populous countries (China and India), each with more than 1 billion people (Hillstrom and Hillstrom, 2003), so with this huge population the changes in the earth surface features and its ecological consequences have been becoming a critical issue and of great interest in Asian countries. Land use change is a major factor for global change because it can affect ecosystem processes; hydrology, biodiversity, climate, biogeochemical cycles and energy balance (Xiao et al., 2006). Global climatic systems and water quality are greatly influence by the changes of land use and land covers (Chen et al., 2001). Land use change also affects soil properties either in a positive or negative ways (Schoorl and Veldkamp, 2001). Deforestation, negatively affects soil properties and enhanced land degradation by reducing land productivity (Fischer and Sun, 2001). For substantial development, municipal authorities need tools to monitor how the land is currently used, assess future demand, and take steps to assure adequacy of future supply; for a better planning of future urban development, municipal authorities need to know situation of urban expansion and in what way it is likely to move in the years to come. The study was conducted-to identify the existing land use of Tangail Municipality using images and to compare the land use changes of Tangail Municipality in 2001, 2011 and 2017 using image.

\section{Materials and Methods}

\section{Study area}

Tangail District is situated in Dhaka division with an area of 3365.30 hectares, is bounded by Jamalpur district on the North and Dhaka and Manikgonj district on the South, Mymensing and Gazipur district on the East, 
Sirajgonj district on the West (Tangail Municipality, 2013). Geographically Tangail Municipality lies on $24^{0} 15^{\prime}$ North Latitude and $89^{0} 55^{\prime}$ East Longitude. It is bounded by Kalihati and Ghatail Upazila on the North,
Nagarpur Upazila on the South, Basail Upazila on the East and Sakhipur Upazilas on the West (Wikipedia, 2014). Fig. 1 shows the Map of Tangail district.

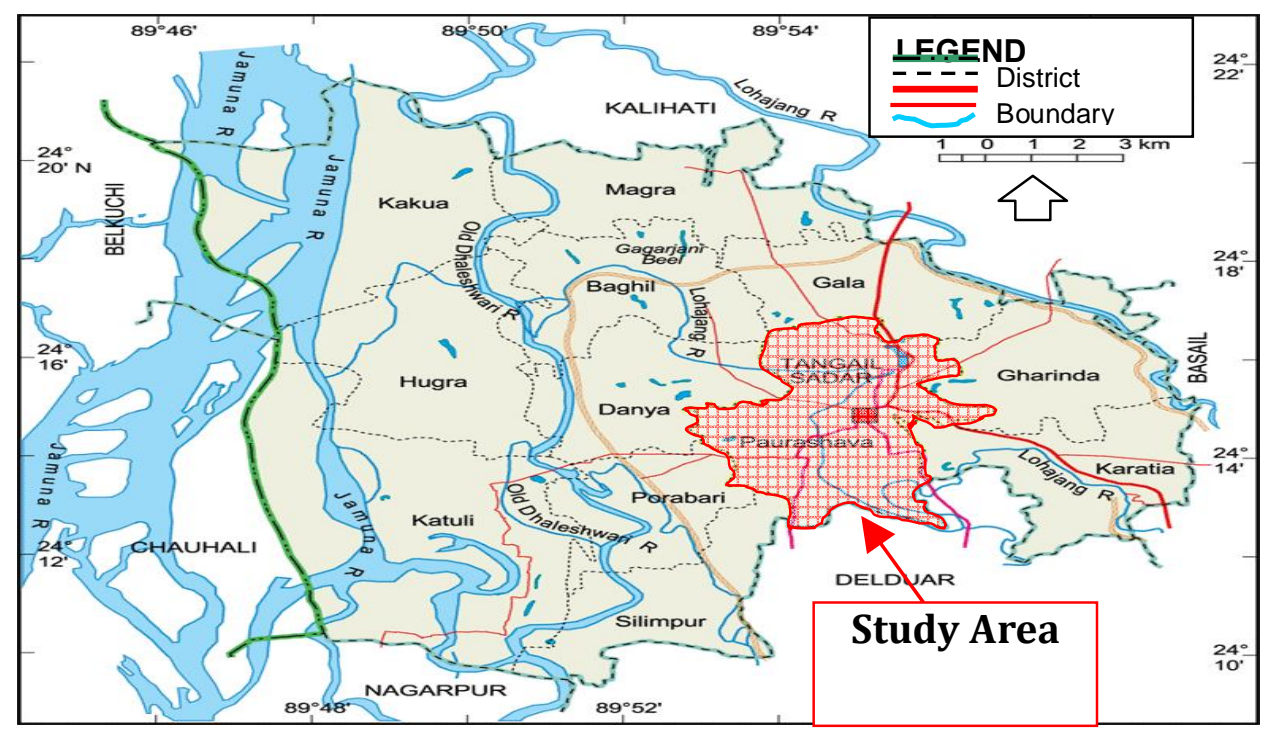

Fig. 1. Map of Tangail district

\section{Remote sensing data}

Landsat TM data of 80 meter resolution of 2011, Landsat OLI data of 30 meter resolution of 2017 covering the study area have been used in the study. Table 1 shows the Landsat TM frame number and dates of study data. TM data were downloaded from U.S. Geological Survey server (http://glovis.usgs.gov). All the captured data had been converted to IMG format.

Table 1. Satellite data used in land use classification of Tangail Municipality

\begin{tabular}{|c|c|c|c|c|}
\hline Satellite & Sensor & Number of Band & Acquisition Time & Frame \\
\hline Ancillary Data & Google & 3 & $31-12-01$ & ------- \\
\hline \multirow{2}{*}{ LAND SAT } & TM & 7 & $07-04-11$ & $137 / 43$ \\
\cline { 2 - 5 } & OLI & 12 & $14-04-17$ & $138 / 43$ \\
\hline
\end{tabular}

\section{Field survey data}

GPS data were collected from field for geo-reference as well as field verification of satellite data interpretation.

\section{Ancillary data}

Google imagery of 2017 has been used for small area settlement delineation using on the screen digitization. The aerial photographs have been used for 2001 and 2011 collected from SPARRSO for the same purpose. Statistical data collected from the Bangladesh Bureau of Statistics (BBS) have been used for validation of remote sensing results.

\section{Data processing and analysis}

The data has been analyzed using GIS software (Arc GIS 10.3.1), Google earth and Microsoft Excel. Satellite image were digitized using Arc GIS 10.3.1 image processing techniques to enable the research of land use image classes. The multi-temporal Landsat imagery has been used which helps identification of perennial and seasonally varying features of land-use. The RGB false color composite has been prepared for visualizing the land features. Then the multi-spectral classification using unsupervised (ISODATA) and supervised classification and results have been compared. 


\section{Results and Discussion}

Changes of land-use such as settlement, agricultural land, water bodies, vegetation area had been analyzed based on the visual interpretation and multispectral digital classification of Landsat imagery. Land use pattern of an area depicts an idea of overall areal utilization of resources, nature or culture. Tables 2 shows the change of land use in Tangail Municipality was evaluated from the differences of different year (2001, 2011 and 2017).

Table 2. Land use changes area (ha) and percentage (\%) of coverage during 2001, 2011 and 2017

\begin{tabular}{|c|c|c|c|c|c|c|}
\hline \multirow{3}{*}{ Land use } & \multicolumn{6}{|c|}{ Year } \\
\hline & \multicolumn{2}{|c|}{2001} & \multicolumn{2}{|c|}{2011} & \multicolumn{2}{|c|}{2017} \\
\hline & Area (ha) & Area $(\%)$ & Area (ha) & Area $(\%)$ & Area (ha) & Area $(\%)$ \\
\hline Water Body & 192.93 & 5.73 & 250.08 & 7.43 & 114.73 & 3.41 \\
\hline Settlement & 735.08 & 21.84 & 1235.06 & 36.70 & 1639.78 & 48.73 \\
\hline Vegetation & 873.01 & 25.94 & 1258.19 & 37.39 & 824.49 & 24.50 \\
\hline Agricultural Land & 1564.27 & 46.48 & 621.97 & 18.48 & 786.30 & 23.36 \\
\hline Total & 3365.30 & 100 & 3365.30 & 100 & 3365.30 & 100 \\
\hline
\end{tabular}

Land use of 2001

The land-use map (Fig. 2) depicts the four broad types of land use of Tangail municipality in the year 2001.

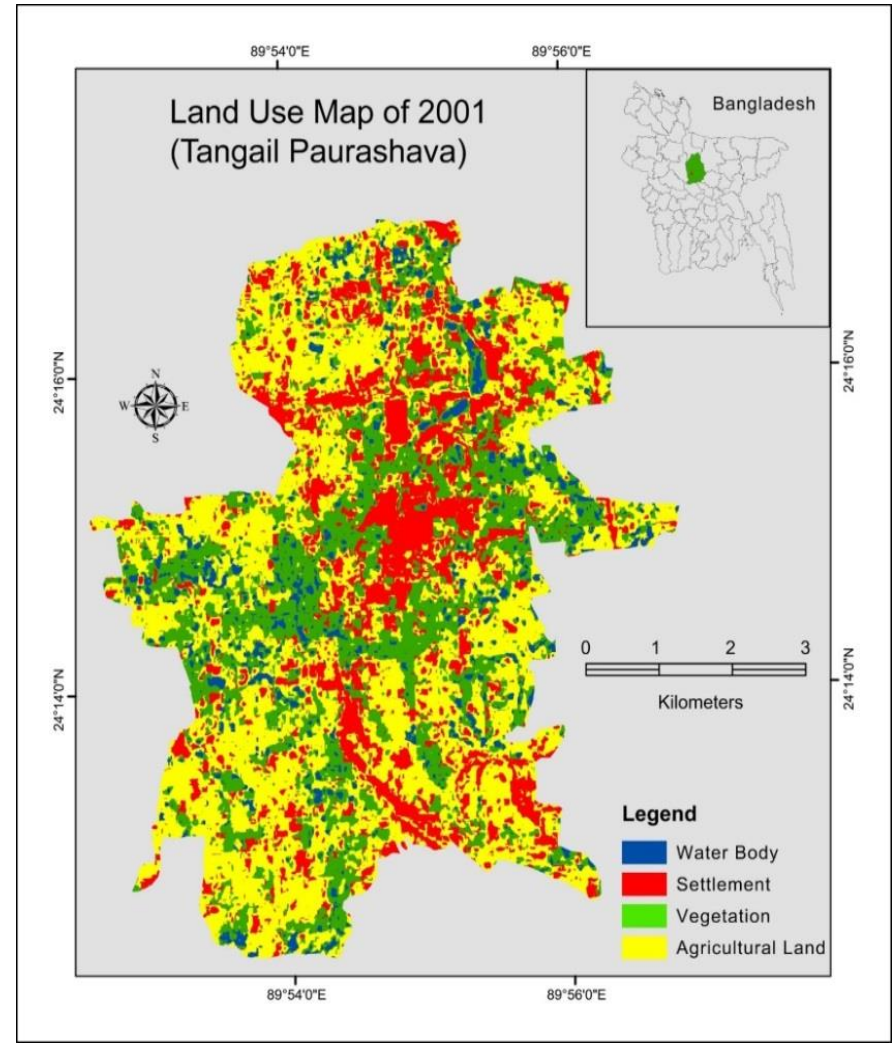

Fig. 2. Land use Map of Tangail Municipality (2001)

It is seen from the Table 2 that, in 2001 the area of agricultural land occupied the highest 1564 hectares and water body area was the lowest 193 hectares. Vegetation

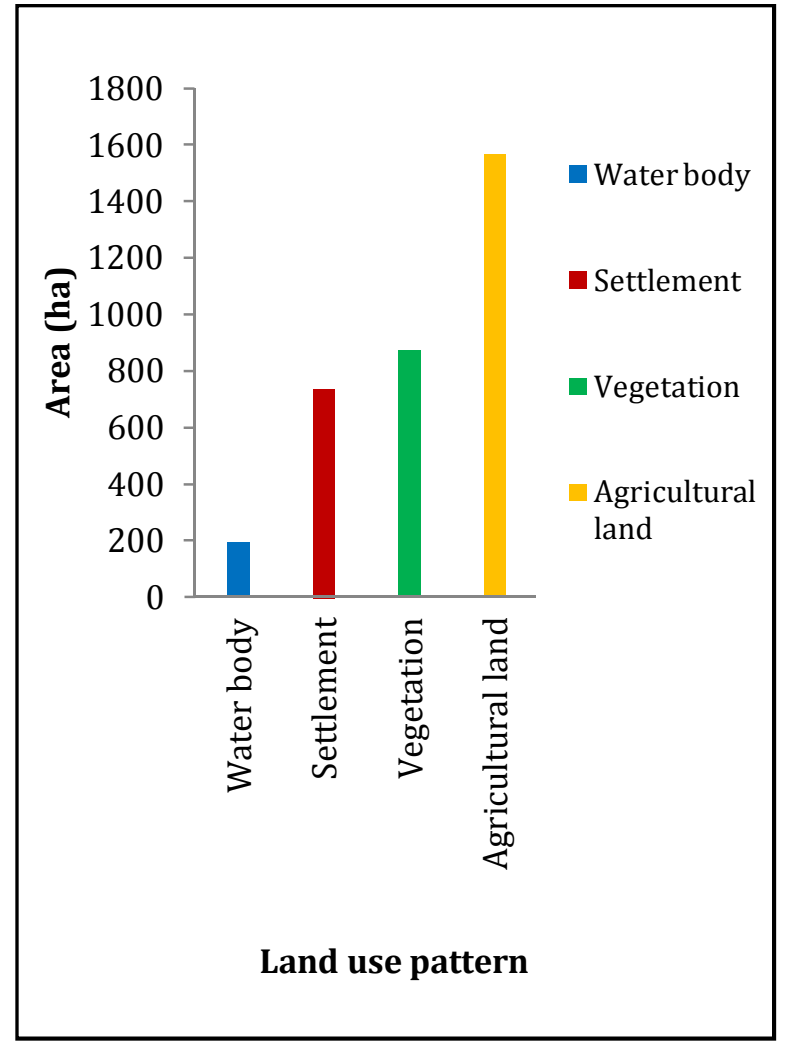

Fig. 3. Land use pattern of Tangail Municipality (2001)

area was about 873 ha. Settlement area was about 735 hectares. This happened mainly due to the establishment of new settlement in this town by the migrated people 
(Islam and Sarker, 2016). With the passage of time the growing population and the faster economic activities had increased thatôs why it had reduced the amount of agricultural land of the city (Ahmed and Hussain, 2012). Fig. 3 shows the land use pattern of Tangail Municipality (2001).

\section{Land use of 2011}

The land use map (Fig. 4) illustrates the types of use of land in Tangail municipality in the year 2011.

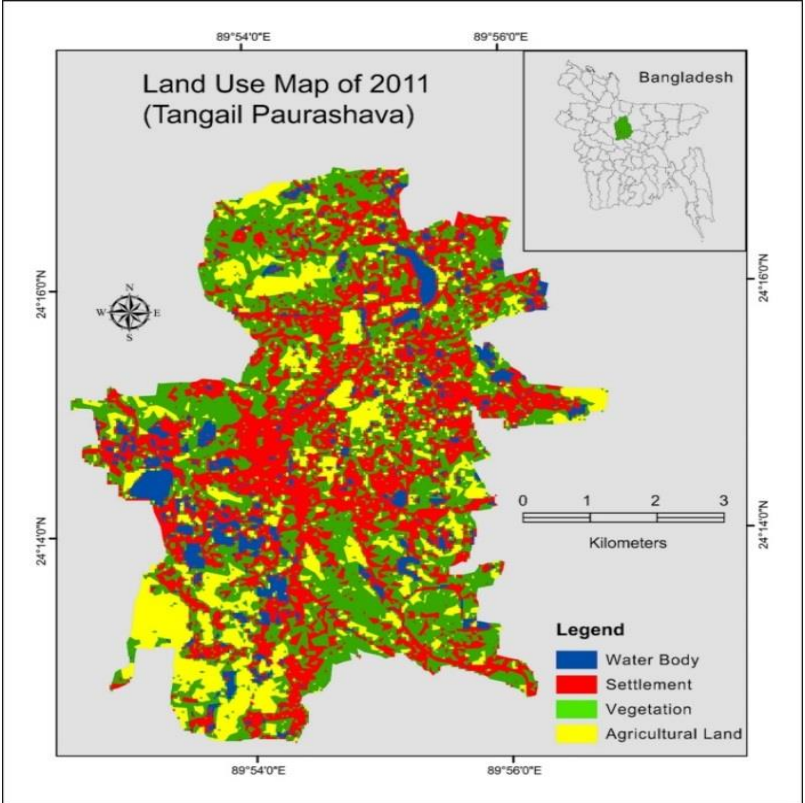

Fig. 4. Land use Map of Tangail Municipality (2011)

From the Table 2, it can be said that in 2011 area of vegetation occupied the highest area was 1258 hectares and agricultural land area was 622 hectares. Agricultural lands are generally used for production of food crops and other crops. There is a marked absence of this land-use in the central part of the study area, mainly due to the dominance of urban built up. Agricultural land decreased and vegetation increased. Agricultural land became

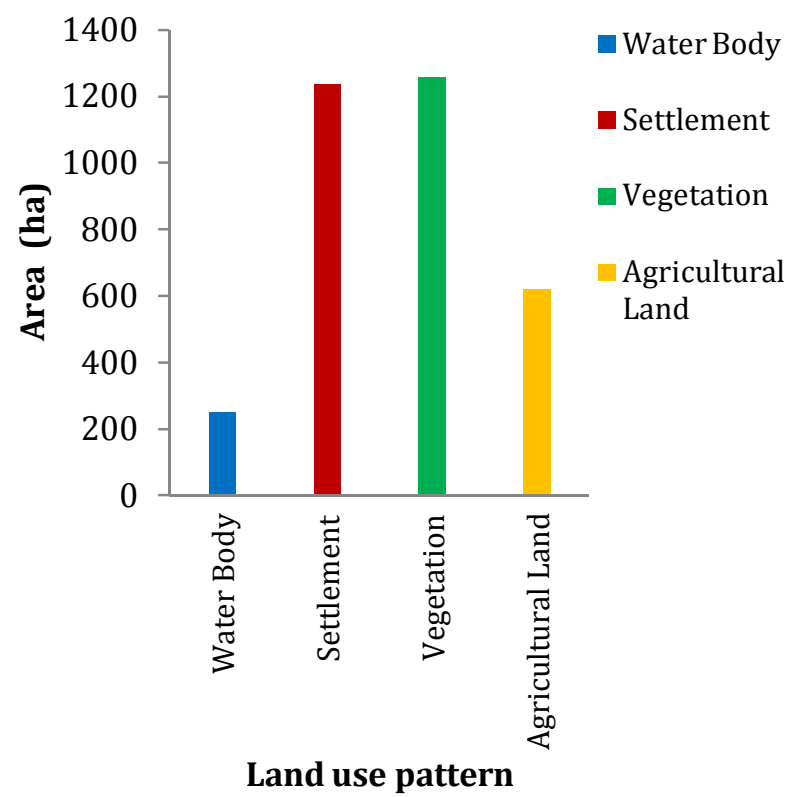

Fig. 5. Land use pattern of Tangail Municipality (2011)

vegetation due to keep it as fallow land. Water body area was 250 hectares and Settlement was 1235 hectares. Fig. 5 shows the land use pattern of Tangail Municipality (2011). Fig. 5 shows the increase of vegetation. This may be due to decrease of water body (This class comprises surface waters either impound in the form of ponds, lakes and reservoirs or flowing as rivers, streams, canals etc.). 
Land use of 2017

In 2017, data analysis resolve shows the land use of Tangail Municipality (Fig. 6).

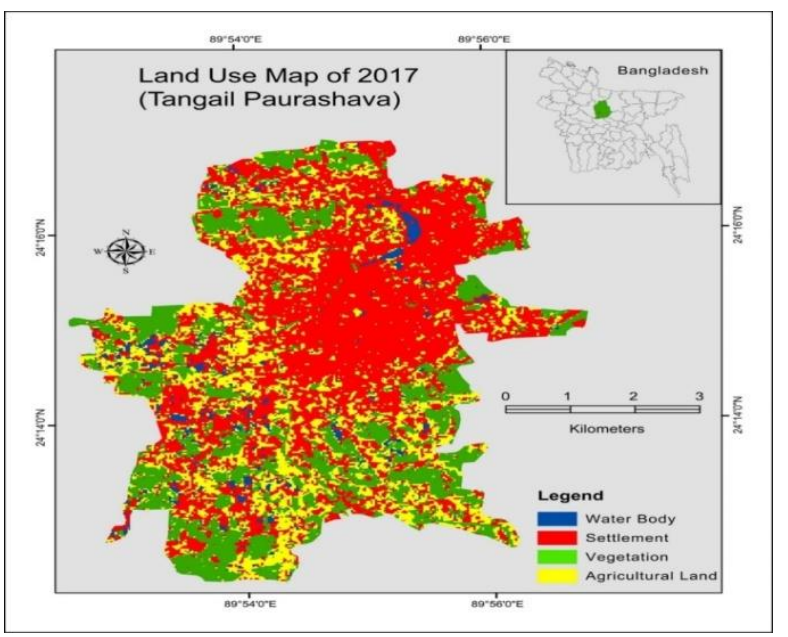

Fig. 6. Land use Map of Tangail Municipality (2017)

It is seen from the Fig. 7 and Table 2 that, in 2017 the area of settlement occupied the highest was 1640 hectares Settlement is increased 12.03 percent in 2017 than the year 2001, which is very obvious due to human population growth. The main settlement areas of this Municipality are Adalat Para, Biswas Betka, Thana Para and Akur Takur Para. Water body area was the lowest

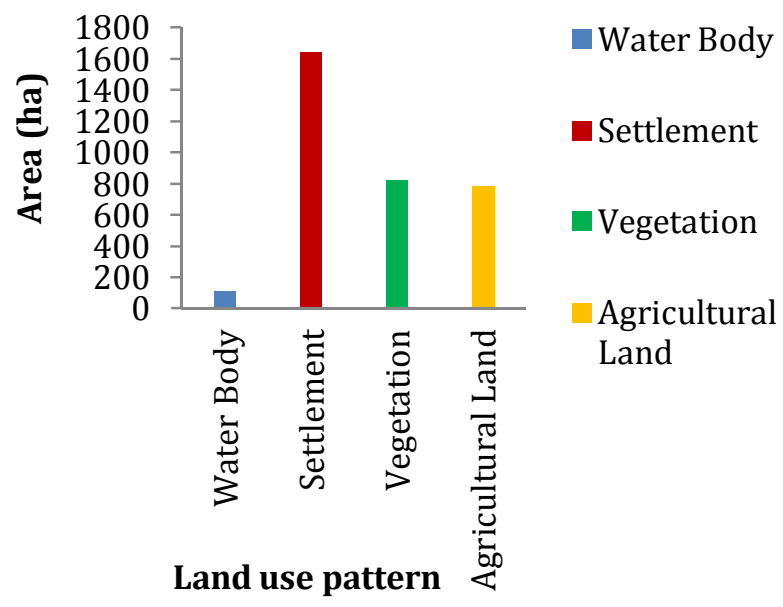

Fig. 7. Land use pattern of Tangail Municipality (2017)

115 hectares. Agricultural land area was found lower 786 hectares than vegetation area 824 hectares. Water body was decreased due to the gradual conversion of water body into settlement area or human development area as the population increased significantly during the past decades (Islam and Sarker, 2016). Fig. 7 shows the land use pattern of Tangail Municipality (2017).

Land use changes 2001 to 2017

Table 2 shows, the land use change pattern during the year 2001, 2011 and 2017. Fig. 8 shows of settlement area change trend.

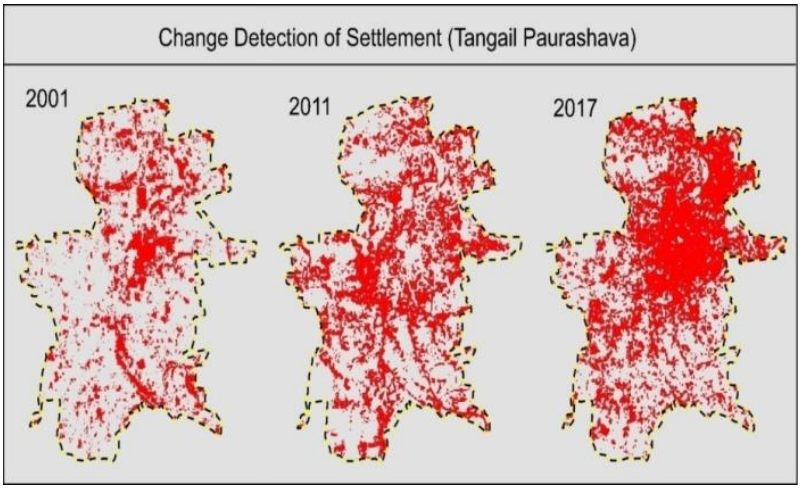

Fig. 8. Changes of settlement in 2001, 2011 and 2017

The area of settlement was occupied 735 hectares, 1235 hectares and 1640 hectares respectively. Observation and data analysis shows that during 2001 to 2011 increase of settlement due to increase of population (Population census 2011) and during 2011 to 2017 increased of settlement due to rapid increase of population (Fig. 9). Land use change is happening due to excessive pressure on and access to city land with rapid development and establishment of a) health and educational infrastructure

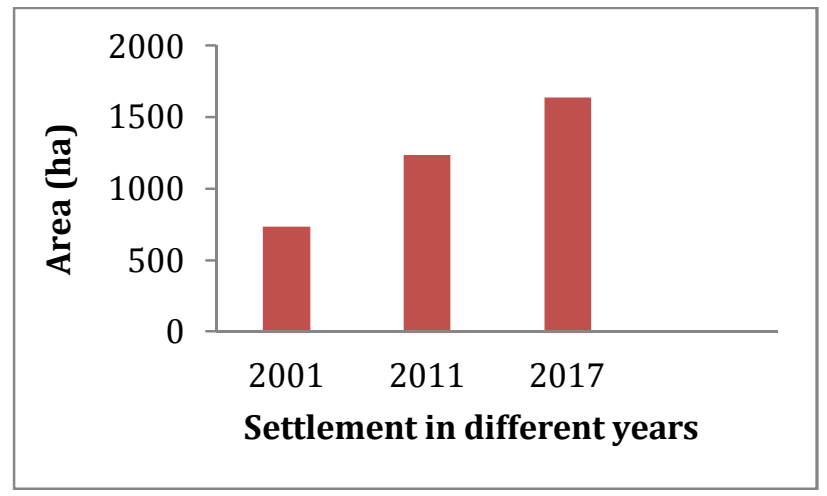

Fig. 9. Changes of settlement in 2001, 2011 and 2017

b) commercial establishments and c) formal and informal settlements (Ahmed and Hussain, 2012). Fig. 9 shows changes of settlement in 2001, 2011 and 2017.Vegetation area was found 873.01 hectares (25.94\%), 1258.19 hectares $(37.39 \%)$ and 824.49 hectares $(24.50 \%)$ of total land during the year 2001, 2011 and 2017 respectively. Data analysis showed that 385 hectares increase of vegetation area in between 2001 to 2011 and 434 hectares decrease in between 2011 to 2017 due to rapid 
increasing of settlement. Vegetation is decreasing with the ratio of population increase. Most of the vegetation areas are visible in North, South-East part of the Tangail municipality (Fig. 10). The changing pattern of land use of the city can be summed up by saying that increase of

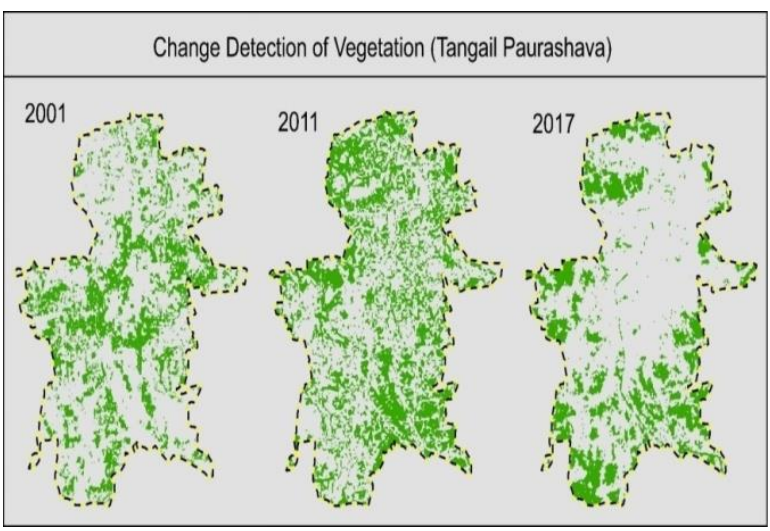

Fig. 10. Changes of vegetation in 2001, 2011 and 2017

Agricultural land area was 1564.27 hectares in 2001. That was the highest (46.48\%) part of used land. But in 2011 agricultural land was decreased two third of 2001 due to increase of vegetation area. People kept agricultural land as fallow land day after day thatôs why agricultural land became vegetation area. In 2017 Agricultural land increased slightly. That happened due

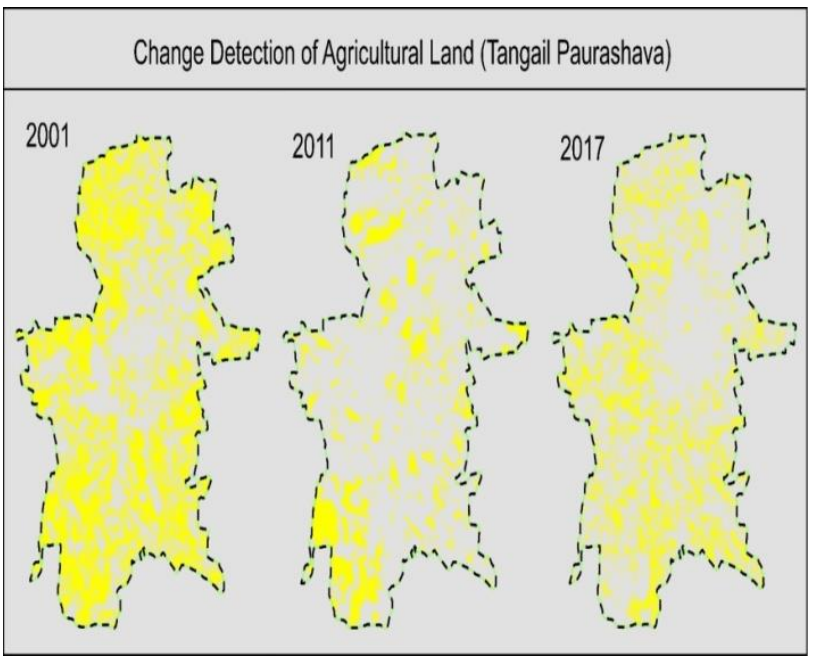

Fig.12. Changes of agricultural land in 2001, 2011 and 2017

Water bodies included wetlands, ponds, streams and rivers. Water body area was 192.93 hectares $(5.73 \%)$ in 2001. In 2011 the area of water body was 250.08 hectares $(7.43 \%)$. In 2017 the area of water body was 114.73 hectares (3.41\%). Water bodies cover only $5.73 \%$ of the total area in the year 2001 which increases to $1.7 \%$ in 2011 probably due to seasonal variation. Data analysis showed 57.15 hectares increased of water body area in residential and commercial area is responsible for decreasing agricultural and industrial land use (Ahmed and Hussain, 2012). Fig. 10 and 11 shows the changes of vegetation in 2001, 2011 and 2017.

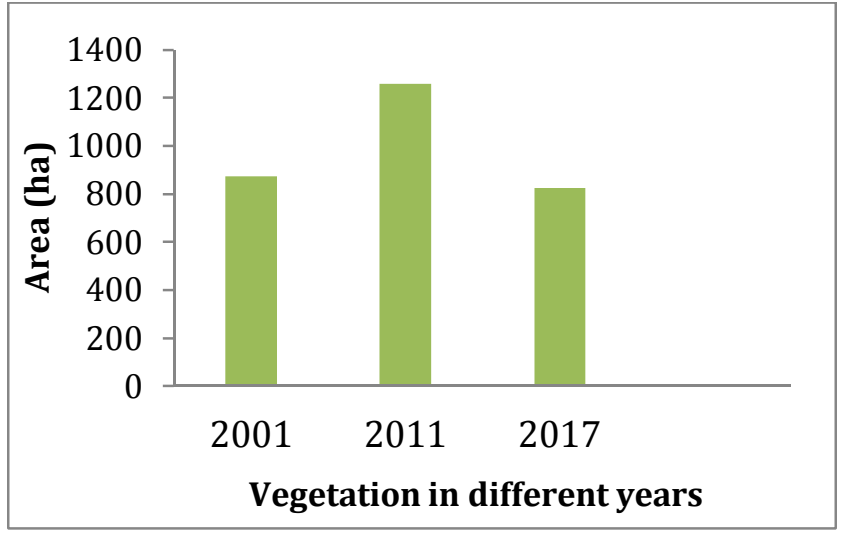

Fig. 11. Changes of vegetation in 2001, 2011 and 2017

to decrease of water body and vegetation area (Fig. 13). Growth of population lead to increasing demand for more agricultural land to produce more food encourages the conversion of others to agriculture (Filius, 1986). Fig. 12 and 13 shows the changes of agricultural land in 2001, 2011 and 2017.

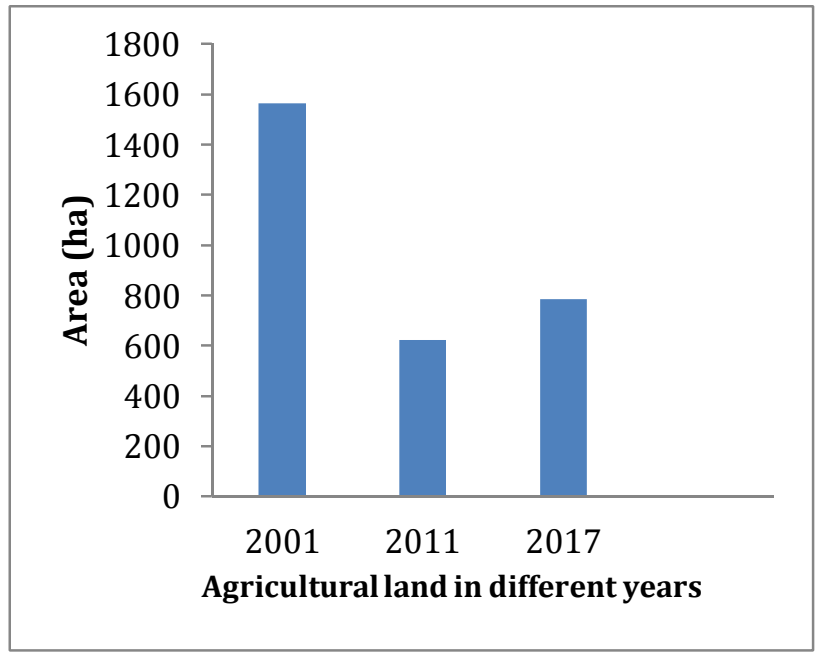

Fig. 13. Changes of agricultural land in 2001, 2011 and 2017

between 2001 to 2011 and 135.35 hectares decreased in between 2011 to 2017 (Fig. 15) due to seasonal variation and filled up the water body by throwing waste or other solid thing and water body decreased. Fig. 14 and 15 shows the changes of water body in 2001, 2011 and 2017. 


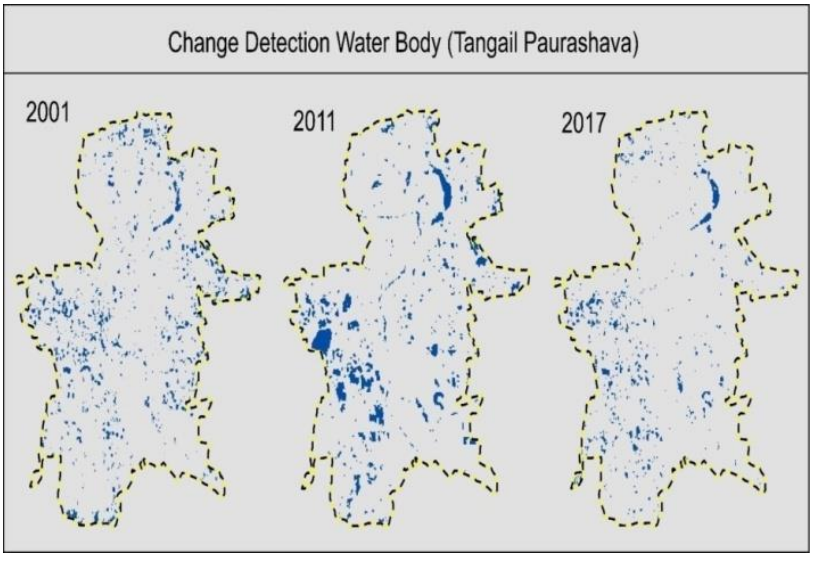

Fig. 14. Changes of water body in 2001, 2011 and 2017

\section{Conclusions}

This study demonstrates the usefulness of LAND SAT or similar remote sensing data for country wise land-use mapping and change detection. The land-use maps have been produced for Tangail Municipality for 3 time frames 2001, 2011 and 2017. The broad land-use features identified are settlements, agricultural land, vegetation areas and water bodies. The results show large changes in the settlement areas and agricultural land. The area of agricultural land has decreased and that of settlement area has increased. The Study shows that about 3365 hectares area of land has been converted urban area during the last 17 years (2001-2017). The area of water bodies in 2001 was about 192 hectare and in 2017 it decreased. Vegetation area also decreased during this year. The cause of intensive land use changes of Tangail Municipality may be attributed to rapid increase of population and unplanned land use. As the study area is threatened by decreasing water bodies and vegetation due to unplanned land use, this study might be helpful to prepare an effective land-use plan for Tangail Municipality to make a planned city.

\section{References}

Ahmed, A and Hussain, S. H., 2012, Changing Urban Land use and Agricultural Land Transformation: A Case Study of Narayanganj City, ASA University Review, 6 (1).

Chen, L.; Wang, J.; Fu, B. and Qiu, Y. (2001). Land use change in a small catchments of northern Loess Plateau, China. Agriculture, Ecosystem and Environment, 86:163-172.

Foley, J. A., De Fries, R., Asner, G. P., Barford, C., Bonan, G., Carpenter, S. R., et al. (2005). Global consequences of land use. Science, 309, $570 і ̈ 574$.

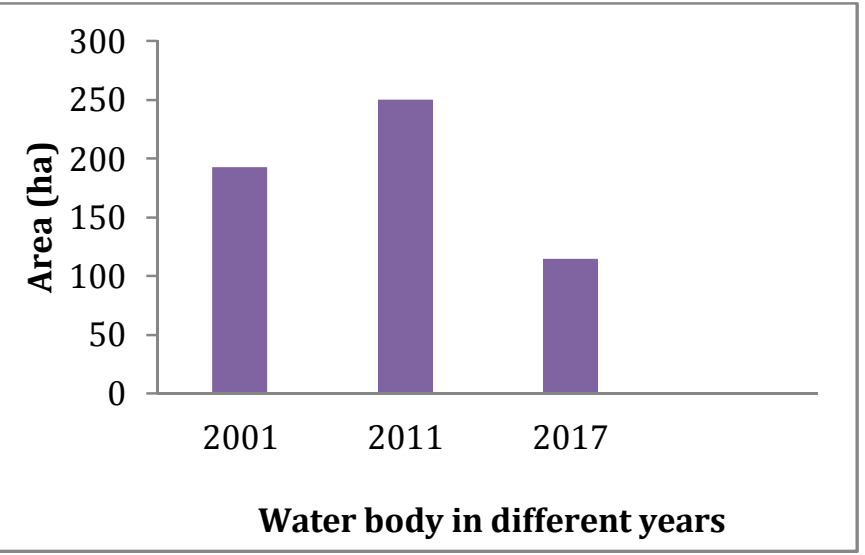

Fig. 15. Changes of water body in 2001, 2011 and 2017

Fisher, G. and Sun, L. (2001). Model Based Analysis of Future land Use Development in China. Agriculture, Ecosystem and Environment, vol.85: pp.163-176.

FAO/UNEP, (1999) The Future of our land: facing the challenge. Guidelines for integrated planning for sustainable management of land resources. pp.71.

Filius, A. M. (1986). Forestry Strategy and land Use Policy in Areas with High Population Pressure. Forest Ecology and Management, 15: 181-193.

Hillstrom, K., \& Hillstrom, L. C. (2003). Asia: a continental overview of environmental issues. ABC-CLIO, Santa Barbara, Last accessed 14th Feb. 2011.

Islam, W. and Sarker, S.C. (2016) Monitoring the Changing Pattern of Land Use in the Rangpur City Corporation Using Remote Sensing and GIS. Journal of Geographic Information System, 8: 537-545.

Ojima, D.S.; Galvin, K.A. and Turner II, B.L. (1994). The Global Impact of Land Use Change. Bioscience, 44(5): 300-304.

Reid, R.S.; Kruska, R.L.; Muthui, N.; Taye, A.; Wotton, S.; Wilson, C. and Mulatu, W. (2000). Land-use and land-cover dynamics in response to changes in climatic, biological and socio-political forces: the case of Southwestern Ethiopia. Landscape Ecology, 15: 339-355.

Schoorl, J.M. and Veldkamp, A. (2001). Linking land use and landscape process modeling: a case study for the Alora region (South Spain). Agriculture, Ecosystem and Environment, 85: 281-292. 
Turner, B. L., Meyer, W. B., and Skole, D. L. (1994). Global land-use/land-cover change: Towards an integrated study. Ambio, 23, (1), Integrating Earth System Science. pp. 91-95.

Vitousek, P. M., Mooney, H. A., Lubchenco, J., \& Melillo, J. M. (1997). Human domination of Earthôs ecosystems. Science, 277: $494 і ̈ 499$.

Xiao J., Shen Y., Ge J., Tateishi R., Tang C., Liang Y. and Huang Z. (2006). Evaluating urban expansion and land use change in Shijiazhuang, China, by using GIS and remote sensing. Landscape and Urban Planning, 75 (2): $69 і ̈ 80$. 